\title{
Evaluation of Corneal Structure and Endothelial Morphological Characteristics in Type 2 Diabetic and Non-Diabetic Patients [Letter]
}

\author{
Mario Graziano ${ }^{1}$ \\ Luigi Capasso ${ }^{2}$ \\ Nicola Rosa (1D) \\ 'Department of Medicine, Surgery and \\ Dentistry, "Scuola Medica Salernitana", \\ University of Salerno, Baronissi, Salerno, \\ Italy; ${ }^{2}$ Corneal Transplant Unit, ASL \\ Napoli I, Naples, Italy
}

\section{Dear editor}

We read with great interest the article by Beato et al about the evaluation of corneal structure and endothelial morphological characteristics in type 2 diabetic and nondiabetic patients. ${ }^{1}$

We would like to congratulate the authors for their impressive paper, because a precise corneal thickness measurement is very important, for example, in evaluating the intraocular pressure ${ }^{2}$ in diabetic patients and we appreciate the authors evaluated the central corneal thickness (CCT) related with the corneal volume, that could better be correlated with eventual endothelial changes. ${ }^{3-6}$

However, we would like to make some comments on this article, because in our opinion there are some points that need to be clarified.

In a previous paper, we found that CCT obtained with Topcon SP-3000P was thinner than the measurements obtained with Pentacam, and we proposed a regression formula to make the measurements comparable. ${ }^{7}$ As the authors utilized the same devices, we wonder if they had a similar experience. ${ }^{8,9}$

Moreover, we read in Table 1 that an important number of the diabetes mellitus (DM) group and not-diabetes mellitus (not-DM) one were affected by systemic hypertension, dyslipidemia and BMI $>25 \mathrm{~kg} / \mathrm{m}^{2}$; we wonder if the similarity between the two groups could be related to the presence of metabolic syndrome, ${ }^{10}$ that probably affected an important number of patients in both groups, and, according to $\mathrm{Su}$ et al, is correlated with a greater CCT.

In our opinion, it would be interesting in a future study to compare the CCT and $\mathrm{CV}$ in DM and not-DM patients in absence of other factors and diseases that could increase CCT.

\section{Disclosure}

The authors report no conflicts of interest in this communication.

\section{References}

1. Beato JN, Esteves-Leandro J, Reis D, et al. Evaluation of corneal structure and endothelial morphological characteristics in type 2 diabetic and non-diabetic patients. Clin Ophthalmol. 2020;14:19931999. PMID: 32764865; PMCID: PMC7369306. doi:10.2147/OPTH.S256244 
2. Lanza M, Borrelli M, De Bernardo M, Filosa ML, Rosa N. Corneal parameters and difference between Goldmann applanation tonometry and dynamic contour tonometry in normal eyes. $J$ Glaucoma. 2008;17:460-464. doi:10.1097/IJG.0b013e31816224bd

3. De Bernardo M, Capasso L, Lanza M, et al. Long-term results of corneal collagen crosslinking for progressive keratoconus. J Optom. 2015;8(3):180-186. PMID: 26105541; PMCID: PMC4502088. doi:10.1016/j.optom.2014.05.006

4. Rosa N, De Bernardo M, Borrelli M, Filosa ML, Lanza M. Effect of oxybuprocaine eye drops on corneal volume and thickness measurements. Optom Vis Sci. 2011;88(5):640-644. PMID: 21358446. doi:10.1097/OPX.0b013e3182114303.

5. Rosa N, De Bernardo M. Central corneal thickness determination in corneal edema. Graefes Arch Clin Exp Ophthalmol. 2017;255 (6):1251-1252. PMID: 28299437. doi:10.1007/s00417-017-3634-9

6. De Bernardo M, Rosa N. Central corneal thickness after cross-linking using high-definition optical coherence tomography, ultrasound, and dual scheimpflug tomography: a comparative study over one year. $\mathrm{Am}$ $J$ Ophthalmol. 2017;176:254. PMID: 28159112. doi:10.1016/j. ajo.2017.01.007
7. De Bernardo M, Borrelli M, Mariniello M, Lanza M, Rosa N. Pentacam vs SP3000P specular microscopy in measuring corneal thickness. Cont Lens Anterior Eye. 2015;38(1):21-27. PMID: 25240777. doi:10.1016/j.clae.2014.08.006

8. De Bernardo M, Vitiello L, Abbinante G, et al. Comparison between two devices in the detection of corneal thickness changes after cataract surgery. Sci Rep. 2021;11(1):6709. PMID: 33758298; PMCID: PMC7988103. doi:10.1038/s41598-021-86158-6.

9. De Bernardo M, Rosa N. Comparison of specular microscopy and ultrasound pachymetry before and after cataract surgery. Graefes Arch Clin Exp Ophthalmol. 2017;255(4):837-838. PMID: 28154931. doi:10.1007/s00417-017-3604-2

10. Su DH, Wong TY, Foster PJ, Tay WT, Saw SM, Aung T. Central corneal thickness and its associations with ocular and systemic factors: the Singapore Malay eye study. Am J Ophthalmol. 2009;147 (4):709-716.e1. PMID: 19152872. doi:10.1016/j.ajo.2008.10.013

Dove Medical Press encourages responsible, free and frank academic debate. The content of the Clinical Ophthalmology 'letters to the editor' section does not necessarily represent the views of Dove Medical Press, its officers, agents, employees, related entities or the Clinical Ophthalmology editors. While all reasonable steps have been taken to confirm the content of each letter, Dove Medical Press accepts no liability in respect of the content of any letter, nor is it responsible for the content and accuracy of any letter to the editor.

\section{Publish your work in this journal}

Clinical Ophthalmology is an international, peer-reviewed journal covering all subspecialties within ophthalmology. Key topics include: Optometry; Visual science; Pharmacology and drug therapy in eye diseases; Basic Sciences; Primary and Secondary eye care; Patient Safety and Quality of Care Improvements. This journal is indexed on PubMed

Submit your manuscript here: https://www.dovepress.com/clinical-ophthalmology-journa
Central and CAS, and is the official journal of The Society of Clinical Ophthalmology (SCO). The manuscript management system is completely online and includes a very quick and fair peer-review system, which is all easy to use. Visit http://www.dovepress.com/ testimonials.php to read real quotes from published authors. 